\title{
business Foreign Aid, Debt, Tax Revenue and Government Spending in South Asia: A Panel Analysis \\ Rozina Akter ${ }^{l}$ and Sakila Aziz Nila ${ }^{2}$
}

\begin{abstract}
Purpose: Over the years, tax revenue, foreign aid, and debt play a prominent role in finance the South Asian countries' government spending. Thus, this paper aims to analyze the effects of foreign aid, debt, and tax revenue on government spending in South Asia.

Methodology: The study considers six south Asian countries over 25 years from 1990-2014. The panel data method is used to analyze the impact of explanatory variables on the dependent variable.

Findings: From the empirical analysis, it is found that foreign aid, tax revenue, and total debt have a positive impact on government spending. It indicates that when these variables increase, government spending also grows significantly. However, a higher interest rate ebbs the volume of receiving debt among the sampled countries.

Originality: Under this circumstance, this paper advocate that rational use of tax revenue may abate the aid dependency and debt burden in South Asian countries.
\end{abstract}

Keywords: Foreign Aid Det, Tax Revenue, Government Spending, South Asia

\section{Introduction}

Foreign aid, debt and tax revenue are significant government spending elements, especially for second and third world countries. The volatile situation of these variables will support political foot ball in any country. In contrast, effective fiscal policy proves that developing countries can graduate from their present condition to the upward direction through the proper functioning of those mentioning macroeconomic variables. In this backdrop, developed countries extend their hands through Official Development Assistance (ODA) in aid, loan, and grants to improve developed and developing countries. Though the developing region of Asia that is South Asian countries are now emerging economies, ODA's reliability contains a large extent of importance as finance. Thin tax bases, narrow export earnings, and low savings are the focal push factors of aid and loan in South Asia. Aid provides for rising technical and consultancy services or providing food and relief to the recipient countries (Morrissey, 2013). Donor countries are becoming concerned about their allotted aid to the recipient countries because of aid fungibility. Aid fungible examines the inefficient use of foreign money, and the ultimate impact of aid is unsatisfactory among the recipient countries (Foster \& Fozzard, 2000; Njeru, 2003; McGillivray \& Ouattara, 2005; Chatterjee et al., 2012; Morrissey, 2012). This continued circumstance falls the recipient countries into a vicious circle of low foreign investment and savings gap (Taha \& Loganathan, 2008). That is why it is a concerning matter of all the branches of the researchers. It is worth mentioning that nowadays, the donor countries have become every strict about giving the ODA and emphasize the recipient countries' fiscal discipline and reasonable policies (Njeru, 2003; McGillivray \& Ouattara, 2005).

Additionally, government spending regulates an economy's growth by adjusting expenditure and income (McGillivray \& Ouattara, 2005). Increasing government expenditure aggrandizes the productivity and employment of an economy. As a result, this economy's business cycle follows the line between booms and recession (Tanner, 1994). Lean tax hamper the economy's growth by shrinking public infrastructure and investment in different sectors like industry, health, and education (Martinez-Vazquez et al., 2012). Apart from this, Tagem (2017) addresses a generalization according to the fact that government spending is composed of foreign aid, debt and tax revenue. On the other hand, tax revenue is the most crucial and highly dependable source of government revenue and spending (Taha \& Loganathan, 2008; Martinez-Vazquez et al., 2012). The development activities are lagged having insufficient tax revenue (Tagem, 2017). Therefore, foreign aid, debt, tax revenue, and government spending are concerning issues of this study. With this reality, it has been observed that developing countries have always given enormous attention to the policies which attract foreign capital through aid and loans (Burnside \& Dollar, 2000; Combes et al., 2016). However, now the question of aid effectiveness has been raised, and the debate starts at the

\footnotetext{
${ }^{1}$ Assistant Director, Money and Banking Division, Research Department, Bangladesh Bank, E-mail: rozina.econ.131515@gmail.com

${ }^{2}$ Economics Discipline, Khulna University-9208, Bangladesh
} 
Business Review- A Journal of Business Administration Discipline, Khulna University, Volume: 14, Number: 1, January-June 2019, pp.17-28 (Print ISSN: 1811-3788; Online ISSN: 2664-3502)

point of how aid inflows affect the recipient government's fiscal behaviour. Having ineffective manages of aid, debt, and loan deteriorates the economy and raises questions on good governance (Bräutigam \& Knack, 2004). Financial shortage decelerates the development activities, and this channel proves when the country economically slow down. South Asian countries have financial constraint to meet domestic needs (Akram, 2016).

In contrast, foreign aid and debt accumulation accelerate the recipient countries' interest and inflation rate. In Sri Lanka, public debt has increased by $100 \%$ to $79.3 \%$ of G.D.P. from 1980 to 2019, respectively (Maitra, 2019). In Pakistan, total external debt has increased from USD 2.7 billion to USD 59.5 billion from 1969 to 2011 (Sijpe, 2012). Total aid in Nepal has raised around $2 \%$ to $10 \%$ of G.D.P from 1960 to 1990 (Bhattarai, 2007). Overall, South Asian economies have a legacy of debt, and they are indebted to over USD 180 billion. Similarly, $25 \%$ of exports in South Asia are being washed away by debt. The foreign debt has surpassed $200 \%$ of export earnings, constituting more than $2 \%$ of their G.D.P. In other words, about $2 \%$ of G.D.P. is just vanished by the debt services (Chaudhury et al., 2000). Having a higher debt burden of a country pushes the economy toward a lower trend (Siddiqui \& Malik, 2013). Hence, South Asian countries actively deal with aid, debt, loan, and tax revenue and mainly depend on those factors. With limited tax revenue, most South Asian countries follow budget deficits that grow vastly over the years (Ouattara, 2006; Herzer \& Morrissey, 2013). Policy conditions of the donorcountry's government spending are influenced by foreign aid and debt, both active and passive (Tagem, 2017). Furthermore, government spending is highly influenced by tax revenue irrespective of country size and any national differences (Oboh \& Isa, 2012). Empirically, it supports that with the same type of foreign aid changes, Kenya and Senegal's debt and tax revenue have different impressions on government spending (Njeru, 2003; Ouattara, 2006). That means government spending has proper relation with these macroeconomic variables. Hence, this research proceeds to analyze the effects of foreign aid, debt, and tax revenue on government spending in South Asia.

Indeed, most of the literature has been focused on their importance, determinants, relationship with factors as trade, different aspects of domestic resource mobilization or tax. However, there is hardly any research done to find the impact on government spending with mentioning variables. Additionally, researchers do not focus on this issue, especially on South Asian countries, whereas those positively regulate South Asian countries. Methodologically, the facts have been examined through panel model estimation on six South Asian countries over 25 years from 1990 to 2014. This paper recognizes and organizes into six sections to achieve the objectives. A brief introduction presents in section one, theoretical and empirical backgrounds offer in section two. Materials and methods are organized in section three; results are explored in section four and section five, namely, discussion. Finally, the concluding remarks are in section six.

\section{Theoretical Background}

Foreign aid, total debt, tax revenue, and the government is spending all of these macroeconomic variables that impact the economy (Taha \& Loganathan, 2008). The inflow of these resources speeds up economic growth by working as an additional investment. Economist Keynes has postulated that efficacious use of distending government expenditure and curtailing of tax base stimulate the economy from the depression (Chaudhury et al., 2000; Ouattara, 2006; Herzer \& Morrissey, 2013; Combes et al., 2016). In this same way, it is observed that the multiplier effect of government spending is not zero by rising national income (Taha \& Loganathan, 2008). Foreign aid is channelled directly through government spending; thus, they influence government fiscal behaviour in developing countries (Tagem, 2017). Foreign aid expands economic growth by supplementing foreign exchange constraints, technical cooperation, and managerial skills vital in many developing countries (Martins, 2009; Herzer \& Morrissey, 2013; Tagem, 2017). W.W. Rostow developed a historical model of development with five stages. These stages are a) traditional society, b) pre-condition for take-off, c) take-off, d) drive to maturity, and e) age of mass consumption. For upgrading from stages two and three, foreign aid and its influence on the economy is discernible (Pankaj, 2005).

Generally, aid is directly given to the government, and it is essential to assess how the government uses it. Feyzioglu et al. (1998) empirically demonstrate that developing countries face fungibility problems mainly for three sectors: education, agriculture, and energy. Similarly, Ve de Sijpe (2012) \& Tagem (2017) have found that a big share of technical cooperation eats up education and health in developing countries. Though aid continuously plays a 
Business Review- A Journal of Business Administration Discipline, Khulna University, Volume: 14, Number: 1, January-June 2019, pp.17-28 (Print ISSN: 1811-3788; Online ISSN: 2664-3502)

substantial role in developing countries, such as channelling resources, the improvement faced by third-world countries is very disappointing (Njeru, 2003). There are two reasons for the negative relationship between aid and spending. The first is reverse causality and the second one is the donors' conditionality (Tagem, 2017). In addition to this, fungibility creates negativity and limits aid effectiveness in stimulating growth. (Foster \& Fozzard, 2000; Njeru, 2003; McGillivray \& Ouattara, 2005; Morrissey, 2012). Another significant element in this research is debt and its impact on government spending. Over many years, most developing countries face twin deficits because they fail to collect enough revenue to finance their budgets. Consequently, to meet up the spending, they rely on debt flows (Akram, 2016). It is suggested that the inflows will successfully and positively influence the developing countries only with the help of proper blending and implication of sound fiscal and monetary policies (Burnside \& Dollar, 2000). In contrast, debt hurts government spending because a considerable amount of budget and foreign aid is used to repay the loans. With passing time, this situation does not change very much but somehow increases the dependency (Chaudhury et al., 2000; Mc Gillivray \& Ouattara, 2005). Moreover, excessive debt burden influences a country's government behaviour and actions by creating vicious cycles, excessive inflationary financing, and excessive taxation on some sectors in the economy.

Finally, tax revenue is the fundamental source of government financing ensuring that the government could make the country more productive and competitive globally (Taha \& Loganathan, 2008). The relationship between tax revenue and government spending is always given significant importance in economics. Tax revenue is regarded as the source of domestic finance, and it has a significant impact on government spending (Mehrara et al., 2011). It has enormous importance worldwide, especially in Asian countries, from the policy perspective (Eita \& Mbazima, 2008; Mehrara et al., 2011). In this regard, a causal relationship between revenue and spending is the most debatable issue (Eita \& Mbazima, 2008; Taha \& Loganathan, 2008; Mehrara et al., 2011). The experimental literature suggests that there are four propositions behind it. The first one is tax-and-spend school;the second one is spend-and-tax school;the fiscal synchronization hypothesis is that the third and fourth and final schools are fiscal neutrality schools (Chang \& Chiang, 2009; Mehrara et al., 2011). It has been observed empirically that a higher tax burden can increase or decrease the economic growth rate (Padda \& Akram, 2009). Consequently, the relationship between economic growth and macroeconomic variables are significant. In developing countries, the impact is evident as they get a massive amount of aid and debt every year and change government spending patterns. Most importantly, foreign aid and debt are given to the recipient countries (developing) to promote their economic development and welfare (Durbarry et al., 1998). In contrast, lack of good governance meansthe low quality of institutions, the status of democracy, tight controls over information, an absence of accountability, a weak role of law, high levels of corruption, and a country's fiscal behaviour. As a result, it is evident in many African countries that government spending and economic growth are negatively influenced by mentioning factors. Moreover, improving governance with better bureaucracy, reducing corruption, maintaining the proper rule of law, managing expenditure, and increasing revenue generation scope can make the growth procedure more sustainable (Bra"utigam, 2004). Similarly, the impact of concerning factors on government spending is a new talk of the research world. This study focuses on foreign aid, debt, and tax revenue on South Asia's government spending.

\section{Materials and Methods}

To analyze the effects of foreign aid, debt, and tax revenue on government spending in the South Asian countries, the researcher employs an econometric model and descriptive statistics.

Sample countries and time frame: South Asian countries such as Pakistan, Nepal, Bhutan, India, Bangladesh, and Sri Lanka are the sample excluding Afghanistan and Maldives. The data has been covered from 1990 to 2014. The specification of the time is because of the data available from 1990. Afghanistan and Maldives have been excluded from the sample countries because of data unavailability.

Data and variables: Along with explanatory variables, foreign aid flows, debt, and tax revenue, the dependent variable is government spending. Most importantly, this research is based on secondary data, and the sources of data are World Development Indicator (W.D.I.), World Bank (W.B.), World Economic Outlook (W.E.O.), Polity database, and State Bank of Pakistan. These sources are authentic to collect the required data. That is why reliable 
and valid data have ensured this study to dissect this research. For examining the data, STATA 12 statistical package has been adopted here. Table 1 postulates the list of variables to recognize the objective properly.

Figure 1 represents the geographical location of the sample countries. Among eight countries, six are considered for data availability, and they are Pakistan, India, Nepal, Bhutan, Bangladesh, and Sri Lanka.

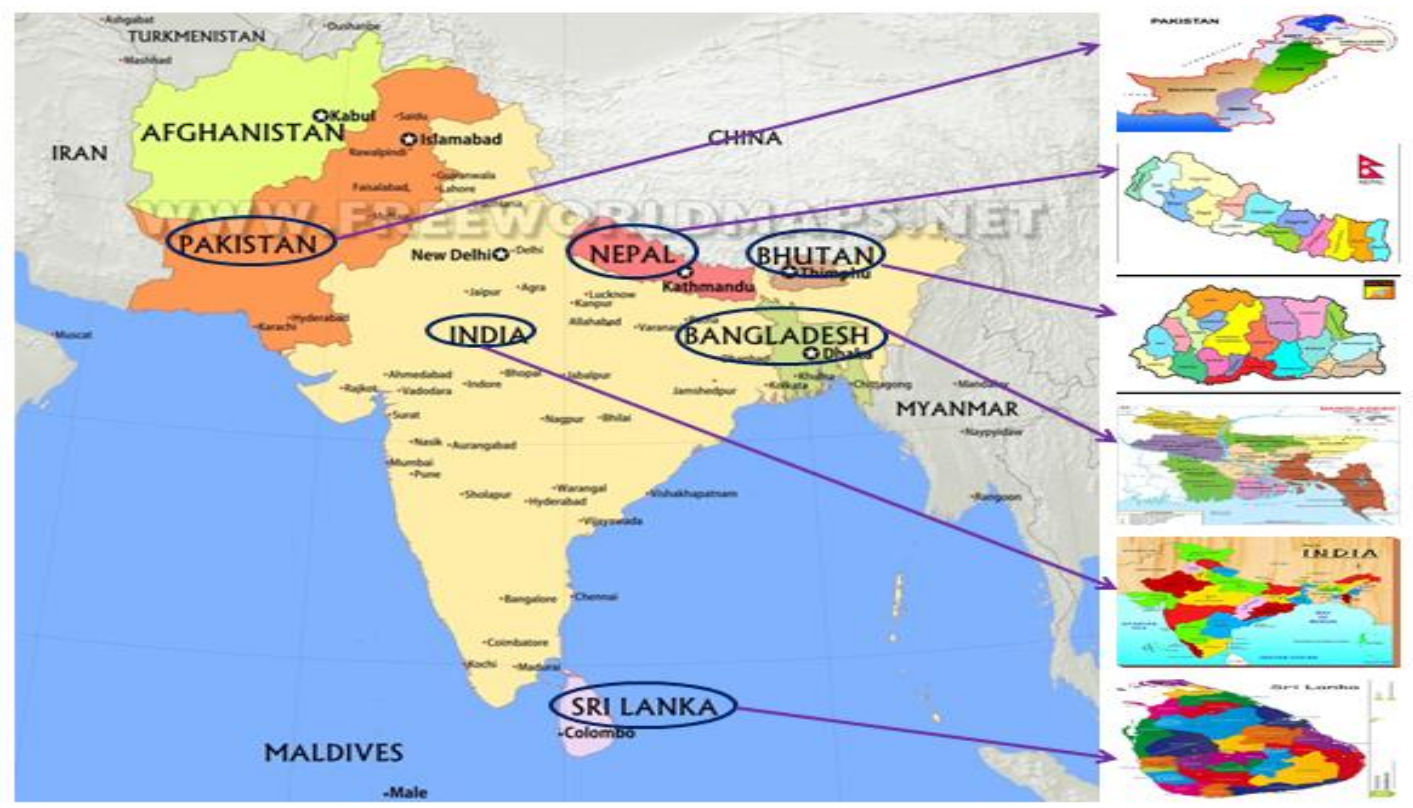

Figure 1: Map of the South Asian Countries

From the list of variables the G.D.P. growth rate indicates how fast the economy is growing. It has a positive influence on government spending (Devarajan et. al., 1996), and government spending captures all types of consumption, investment, and transfer expenditure of the government. Here, government spending is the dependent variable. The third one is foreign aid, and it is the assistance in developing and low-income countries from developing countries in the form of a grant, gift or loan. Remmer (2004) suggests that foreign aid is directly related to government spending. Tax revenue is a vital source of government financing. Government spending and tax revenue are positively influenced by each other. That means present government spending is influenced by future tax revenue, and the inverse is also true (Anderson et al., 1986).

Table 1: Variables for Addressing the Objective

\begin{tabular}{|l|l|l|l|}
\hline \multicolumn{1}{|c|}{ Variable } & Unit of Measurement & \multicolumn{1}{c|}{ Symbol } & \multicolumn{1}{c|}{ Source of Data } \\
\hline G.D.P. growth rate & $\%$ & GDPGro & W.D.I., 2017 \\
\hline Government spending & $\%$ of G.D.P. & GovSp & W.D.I., 2017 \\
\hline Foreign aid & $\%$ of G.D.P. & FoAid & W.D.I., 2017 \\
\hline Tax revenue & $\%$ of G.D.P. & TaxRe & W.D.I., 2017 \\
\hline Total debt & $\%$ of G.D.P. & Debt & W.D.I., 2017 \\
\hline Trade openness & $\%$ of G.D.P. & TrOp & W.D.I., 2017 \\
\hline Total reserve & $\%$ & ToRe & W.D.I., 2017 \\
\hline Urbanization & $\%$ of total population & Urb & W.D.I., 2017 \\
\hline Industrialization & \% of G.D.P. & Indus & W.D.I., 2017 \\
\hline Interest rate & $\%$ of G.D.P. & IntR & $\begin{array}{l}\text { W.D.I., 2017; } \\
\text { State Bank of } \\
\text { Pakistan, 2017 }\end{array}$ \\
\hline
\end{tabular}


Business Review- A Journal of Business Administration Discipline, Khulna University, Volume: 14, Number: 1, January-June 2019, pp.17-28 (Print ISSN: 1811-3788; Online ISSN: 2664-3502)

\begin{tabular}{|l|l|l|l|}
\hline Investment & \% of G.D.P. & Inves & W.E.O., 2017 \\
\hline Current account balance & \% of GDP & CAB & WDI, 2017 \\
\hline Democracy & Index value (1 to 10) & Demo & $\begin{array}{l}\text { Polity4 } \\
\text { database, 2017 }\end{array}$ \\
\hline Constraints on the executive & Index value (1 to 7) & ConEx & $\begin{array}{l}\text { Polity4 } \\
\text { database, 2017 }\end{array}$ \\
\hline Political Competition & Index value (1 to 10) & PoCo & $\begin{array}{l}\text { Polity4 } \\
\text { database, 2017 }\end{array}$ \\
\hline Inflation & $\%$ & Infla & W.D.I., 2017 \\
\hline Population & Number & Pop & W.D.I., 2017 \\
\hline
\end{tabular}

[Note: W.D.I. means World Development Indicator; W.E.O.means World Economic Outlook]

Sequentially, budget constraint is removed from the availability of debt (Bohn, 1998). Trade openness implies the total share of export and import of goods and services of G.D.P. Trade openness has a positive relationship with government spending in the education sector, especially for low-income countries (Benarroch \& Pandey, 2012). Banks and other financial institutions hold a certain amount of depository amount as a reserve to secure themselves (Feinman, 1993). After that, urbanization is considered as an important explanatory variable. Urbanization increases the demand for government spending in different public services (Carruthers \& Ulfarsson, 2003). Abizadeh \& Yousefi (1996) argue that government expenditure boosts up with the stimulation of industrialization that following, the interest rate is the cost of money. If the number of debt increases, then the cost of money rises (Laubach, 2009). Similarly, investment is one of the crucial components of government spending, and it can conclude that there is a direct relation between them. Institutionalized constraints on chief executive decision-making powers are considered constraining to the executive (Glaeser et al., 2004). Political competition states how many parties are participating in attaining political power, and their influences and behaviour are also investigated (Stigler, 1972). Inflation defines the general increase in the price level. Higher inflation influences government deficit with the indication of rising government spending (Dwyer Jr, 1982). Lastly, a growing population means augmenting government expenditure on consumption, investment, and transfer payment.

Analytical approach: For recognizing objective, the researcher has used the panel regression method. Well-known panel regression models are pooled O.L.S. model, within-group fixed-effect model, and random effect model. In this study, six countries (i) and 25 years ( $t$ ) are considered to analyze the impact of aid, debt, and tax revenue on government spending. Having some limitations of pooled O.L.S., this method is unable to produce an acceptable result. The shortcoming of the pooled O.L.S. method is that it does not distinguish the country-specific characteristics. To specify the unobserved country-specific effect fixed effect (F.E.) and random effect (RE) models have been incorporated. To decide between fixed and random effect the Hausman test has been done. Here only the fixed effect values have been incorporated as per the results of the Hausman test. The tests' p-value is below 0.05; that is, the alternative hypothesis (fixed effect) has been accepted. The fixed effect is used to analyze the impact of variables that vary over time. Fixed effect removes time-invariant characteristics and time-invariant characteristics are unique to the individual and should not be correlated with other individual characteristics. The model is thus-

$$
Y_{i t}=\beta_{0}+\beta_{k} X_{k i t}+\alpha_{i}+\mu_{i t}(1)
$$

Where, $\alpha_{i}$ is the unknown intercept for each country. $Y$ is dependent (government spending) and $X$ refers to independent variables, $\beta_{0}$ refers to the constant term, $\beta_{k}$ refers set of the coefficients of the explanatory variables, $\mathrm{X}_{\mathrm{k}}$ refers to the set of explanatory variables, and $\mu$ is the error term. Here $\mathrm{i}=$ entity and $\mathrm{t}=\mathrm{time}$. The major side effect of fixed-effects models' features is that they cannot investigate the dependent variable's time-invariant causes.

\section{Results}

Debt and tax revenues from public spending in South Asian countries, both descriptive and empirical analyses of foreign aid's impact, are being realized for more robust evidence. 
Result from descriptive analysis: Basically, the South Asian region has eight countries: Afghanistan, Bangladesh, Bhutan, India, Maldives, Nepal, Pakistan, and Sri Lanka. The countries have similarities according to shared characteristics and dissimilarities, such as geographical variation, different constitutional rules, regulations, and relationships with different countries, based on the international political environment, governance system, and population density. There will be different receiving aid trends, taking loans, getting tax revenue, and government spending. The country-specific foreign aid trends, loans, tax revenue, and government spending have presented graphically in Figure 2.

South Asian countries largely depend on aid inflow and external debt for apparent reasons. The importance of foreign aid and debt for the economy of South Asian countries is enormous. According to Figure 2, all four variables, like foreign aid, debt, tax revenues, and government spending, are unstable over most countries. For Bangladesh, government spending is volatile, foreign aid and debt follow a direction towards downward sloping. In contrast, tax revenue pursues an upward trend. Currently, all four variables are evidence of an unstable situation in Bhutan. India has the most robust economic system in South Asia, and the graph justifies it. The government of Nepal's spending reveals an upward sloping trend after 2006. Besides, they are losing their appearance to attack foreign aid. For this, tax revenue becomes the primary source of government spending. Alternatively, debt tries to maintain a constant trend, particularly. For Pakistan, both government expenditure and tax revenue, maintain zig-zag relations, but the debt amount surpasses foreign aid. Donor countries disperse their outlook towards other South Asian countries rather than Pakistan. Overall, the economy can face emotional troubles soon. Lastly, all four macroeconomic variables perform poorly in Sri Lanka. Foreign aid donor countries do not want to invest in Sri Lanka. Government expenditure ebbs its size because of having an insufficient volume of financing. It can be concluded that the development of foreign aid, debt, tax receipts, and public spending in South Asian countries is highly uncertain. In some countries, the trends represent a high level of fluctuations overall. Similarly, from reviewing the literature, visual evidence justifies the early evidence that debt and tax revenues influence government spending.
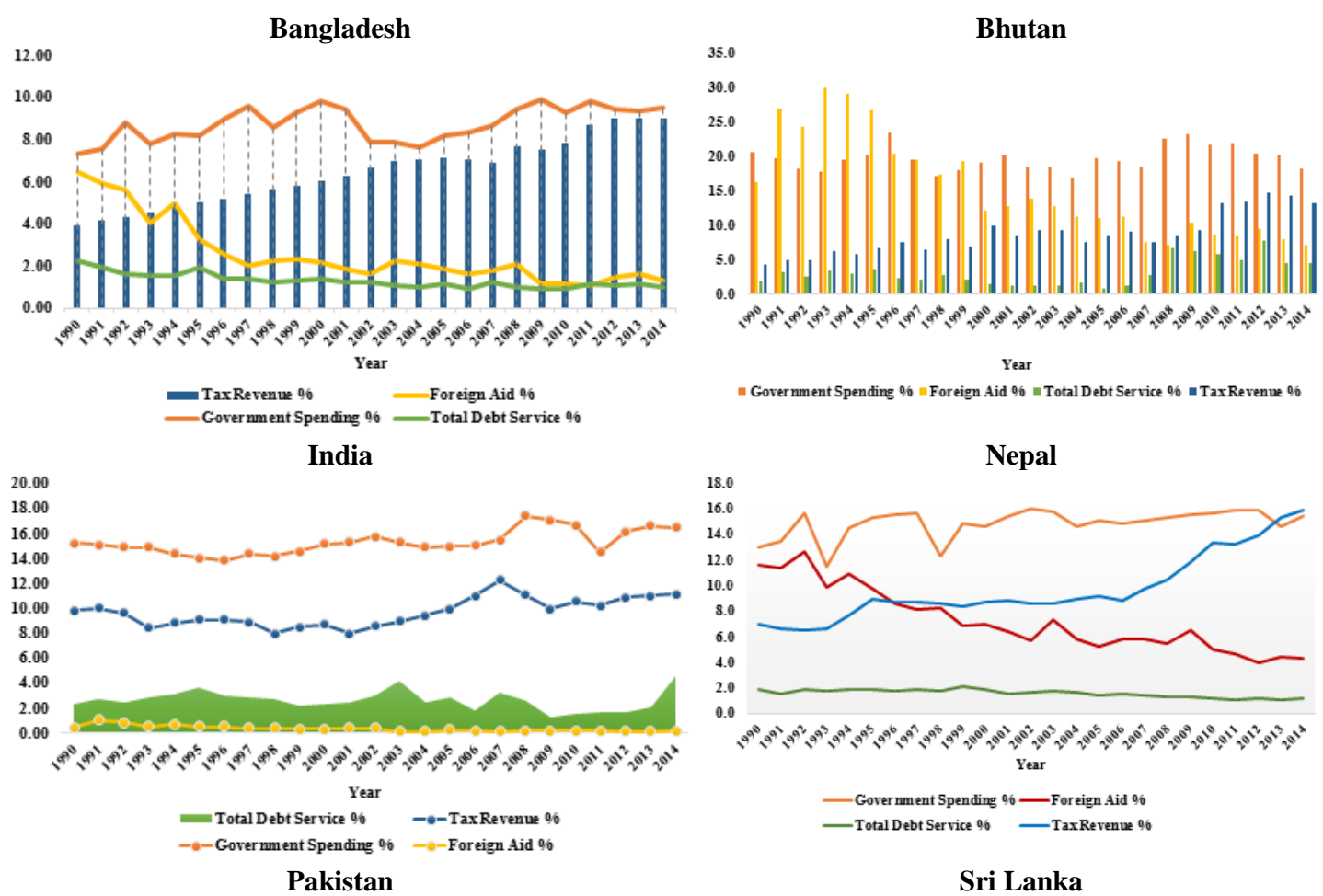

Figure 2: Trend of Foreign Aid, Debt, Tax Revenue, and Government Spending 

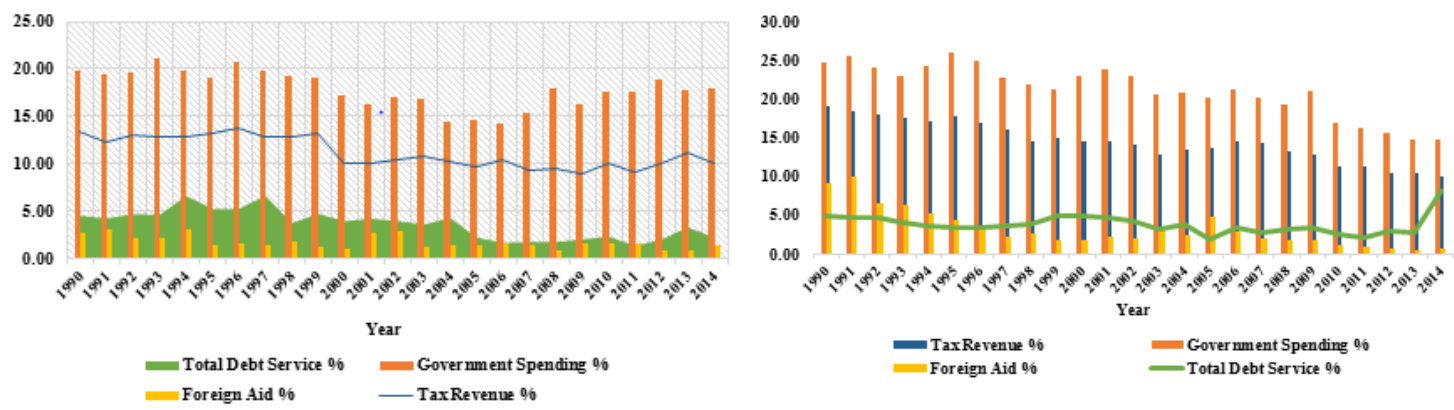

Source: Authors' compilation based on W.D.I., 2017

Table 2 presents the summary statistics of all the sample countries' variables and values in the form of mean and standard deviation and shows the particular country's economy. Compared to the rest of the country, Bangladesh has average revenue earnings of $6.54 \%$. The highest average amount of earnings belongs to Sri Lanka, with $14.46 \%$. The result justifies that Sri Lanka must collect the lion's share of government spending domestically. Lower earnings hinder the capacity of spending compare to the other countries. On average Bangladesh's government spending has $8.74 \%$, and Sri Lanka has the highest amount $21.13 \%$.

Table 2: Summary Statistics on South Asian Countries

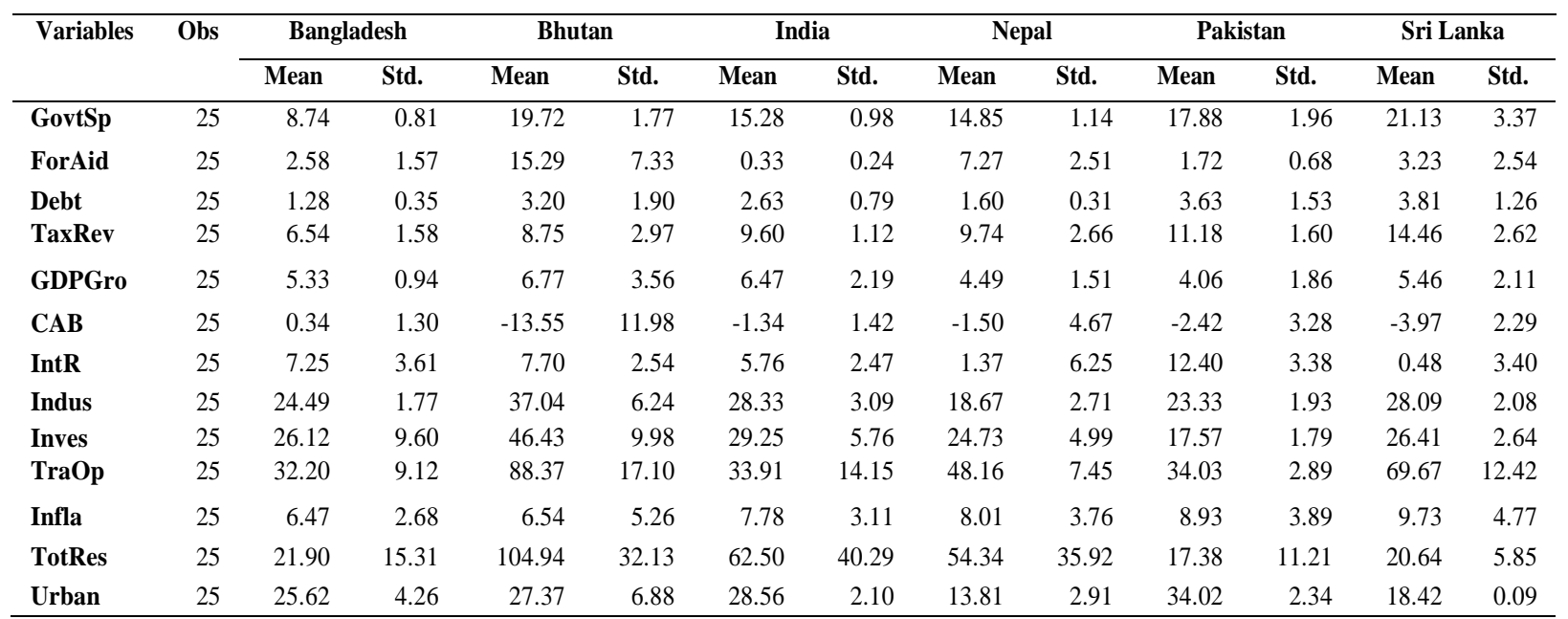

Source: Authors' compilation based on W.D.I. 2017

[Note: Obs. means observation, Std. means standard deviation. The variables are- GovtSp = government spending, ForAid $=$ foreign aid, Debt $=$ total debt, TaxRev $=$ tax revenue, GDPGro $=$ GDP growth, CAB $=$ current account balance, IntR $=$ interest rate, Indus $=$ industrialization, Inves $=$ investment, TraOp $=$ trade openness, Infla $=$ inflation rate, TotRes $=$ total reserve and Urban $=$ urbanization $]$

Empirical analysis: Consequently, two within-group fixed-effect models have been performed to reach the objective. At first, the estimation process considers all the selected variables to examine the effect on government spending. Foreign aid, tax revenue, current account balance, and trade openness are significantly related to government spending. This finding justifies the literature statement. The researcher has postulated debt and interest rate in the form of an interaction variable. It has been interacted to examine the specific effect of debt when the rate of interest is individual. It is noticeable in developing countries that a considerable amount has been used to pay interest to receive debts each year. In model two, some political variables are considered in this research to examine how South Asian countries' government spending behaves in their presence. Considering variables are democracy, 
constraints on the executive and political competition. Economics and politics are always close to each other. These variables are imperative for analyzing the economic decisions that have been taken place in South Asian countries. Including the indexed values from Polity4 database, 2017, where one is the lowest and 10 is the highest value of democracy and political competition and constraints on the executives has a value from 1 to 7 . For these reasons, the interactions have been incorporated into the model with the essential estimation. At the same time, government spending is the dependent variable for all the models.

Table 3 presents the results of the within-group fixed-effect model. The second column is for model 1 represents the values of all the considered variables. It is shown that if there is a $1 \%$ increase in foreign aid, the government spending of South Asian countries will increase by $0.19 \%$, and the result is significant at a $1 \%$ level. The logic behind, the result is when foreign aid increases the financial ability and enhances its spending capacity. By increasing $1 \%$ of the debt, the spending is increased by $0.17 \%$. The government typically takes loans to fulfil the budgetary needs, but the result is insignificant with characteristic signs. By increasing $1 \%$, tax revenue, government spending will be increased by $0.49 \%$ of South Asian countries. The result is significant at the $1 \%$ level. It is selfevident as tax revenue is the domestic earning source. A $1 \%$ increase in the current account balance will increase the spending by $0.05 \%$ with a $5 \%$ significance level. Finally a $1 \%$ increase in trade openness will increase the spending by $0.05 \%$ with a $1 \%$ significance level. All the models have considered six countries and 150 observations. $R^{2}$ Value for model 1 shows that the explanatory variables explain the dependent variable by $51 \%$. The third column of Table 3 represents the inclusion of the interaction variable debt and interest rate. The estimated result is insignificant, but the sign is positive. Increasing interest rates negatively affects the performance of debt, and the ultimately combined effect increase government spending. Hence, this study finding complies with a bunch of literature.

Table 3: Results of Within Group Fixed Effect Model (FE)

\begin{tabular}{lrrrrr}
\hline Explanatory Variables & \multicolumn{2}{c}{ Model 1 } & \multicolumn{1}{c}{ Model 2 } \\
\cline { 2 - 6 } & Estimation 1 & Estimation 2 & Estimation 3 & Estimation 4 & Estimation 5 \\
\hline Foreign Aid & $0.19^{* * *}$ & $0.19^{* * *}$ & $0.23^{* * *}$ & $0.21^{* * *}$ & $0.23^{* * *}$ \\
Debt & 0.17 & 0.07 & 0.13 & 0.15 & 0.16 \\
Tax Revenue & $0.49^{* * *}$ & $0.48^{* * *}$ & $0.46^{* * *}$ & $0.46^{* * *}$ & $0.47^{* * *}$ \\
Current Account Balance & $0.05^{* *}$ & $0.05^{* *}$ & $0.07 * *$ & $0.06^{* *}$ & $0.06^{* *}$ \\
Interest Rate & 0.05 & 0.02 & 0.04 & 0.04 & 0.05 \\
Investment & -0.03 & -0.03 & -0.02 & -0.02 & -0.02 \\
Trade Openness & $0.05^{* * *}$ & $0.05^{* * *}$ & $0.05^{* * *}$ & $0.05^{* * *}$ & $0.05^{* * *}$ \\
Inflation & 0.04 & 0.04 & 0.03 & 0.03 & 0.03 \\
Total Reserve & 0.0003 & -0.00010 & 0.0008 & 0.0005 & 0.002 \\
Population & -0.001 & -0.001 & -0.002 & -0.001 & -0.003 \\
Debt*Interest rate & - & 0.01 & - & - & - \\
Democracy & & & $0.06 *$ & - & - \\
Constraint on Executives & & & - & $0.17^{*}$ & - \\
Political Competition & $7.9 * * *$ & $8.22 * * *$ & $8.02 * * *$ & $7.47 * * *$ & $7.26^{* * *}$ \\
Constant & 150 & 150 & 150 & 150 & 150 \\
Observations & 0.51 & 0.51 & 0.52 & 0.52 & 0.52 \\
R-squared & 6 & 6 & 6 & 6 & 6 \\
Number of countries & 6 & & - & $-13^{*}$ \\
\hline
\end{tabular}

Source: Authors' compilation based on W.D.I., 2017; W.E.O., 2017; Polity4 Database, 2017 and State Bank of Pakistan, 2017

[Note: Dependent variable is government spending. $* * * \mathrm{p}<0.01, * * \mathrm{p}<0.05, * \mathrm{p}<0.1$. W.D.I. means World Development Indicator and W.E.O.means World Economic Outlook]

The estimated result proceeds with the individual presence of the political variables and all other measured variables. To analyze the effect, democracy incorporated in the model show cased as estimation 3 , the constraint on 
executives and political competition is included an estimated 4 and 5 . There is a very slight difference between the three models. The estimated value of estimation 3 and 5 have the same government spending level due to a change in aid. If there is a $1 \%$ increase in foreign aid, then the government spending of South Asian countries will increase by $0.23 \%$, and the result is significant at a $1 \%$ significance level. In estimation 4, if there is a $1 \%$ increase in foreign aid, then South Asian countries' government spending will increase by $0.21 \%$. This result is statistically significant at a $1 \%$ level. By increasing $1 \%$ of the debt, government spending will be increased by $0.13 \%$ (estimation 3 ), 0.15 $\%$ (estimation 4), and $0.16 \%$ (estimated 5). However, the result is statistically significant with the expected sign. Accordingly, if there is a $1 \%$ increase in tax revenue, government spending will be increased by $0.46 \%$ (estimated 3 and 4) and $0.47 \%$ (estimation 5) of South Asian countries. The result is statistically significant at the $1 \%$ level.If there is a $1 \%$ increase in the current account balance, it will increase the spending by $0.07 \%$ (estimation 3 ) and 0.06 $\%$ (estimation 4 and 5), which is statistically significant at $5 \%$. A $1 \%$ increase in trade openness will then enhance the spending by $0.05 \%$ for both models, which is statistically significant at $1 \%$. The results of estimation three have included democracy, and it has been analyzed that, with each increasing level of democracy, there will be a $0.06 \%$ increase in countries' government spending. The result is statistically significant at the $10 \%$ level Then constraint on the executives as the explanatory variable; it has been estimated that, if the executives' constraint increases, there will be a $0.17 \%$ increase inSouth Asian countries' government spending. It is also statistically significant at the $10 \%$ level. The last column of the table results in the model included a political competition where it has been found that there will be a $0.06 \%$ increase in government spending with each increasing level of political competition. The result is statistically significant at the $10 \%$ level Lastly, the value of $R^{2}$ The model is 0.52 ; that is, the explanatory variables explained about $52 \%$ variation of the dependent variable (government spending), and it is the same for all the three estimations of model 2 . In this backdrop, the relation between explaining and explanatory variables follows the theoretical and empirical outcomes.

\section{Discussions}

Findings of descriptive statistics: Foreign aid, debt, tax revenues, and government spending are unstable over South Asian countries. All the sampled countries are dependent on the world's domineering countries having a budget deficit in every fiscal year. Foreign aid provides for the development of social and economic development. However, the expectation is mainly on the air. Some backdrops of getting foreign aid are enumerated here. Those are economic connectivity failures, democratic governance, geographical location, internal conflict, harmony and security, terrorism attack, inadequate infrastructure, and ineffective policy recommendation and implementation. Receiving debt is a concerning matter because the recipient countries have to pay both capital and interest at maturity time. Low foreign aid and limited debt have a significant tax relation because the deficit part should be fulfilled by increasing its tax. During the sampled year, tax revenue is $6.54 \%$ in Bangladesh and $14.46 \%$ in Sri Lanka. Sri Lanka is gradually losing its appeal to attract donor countries.

Findings from regression results: Consequently, two within-group fixed-effect models have been performed to reach the objective. In those regressions, government spending is controlled by foreign aid, debt, tax revenue, current account balance, trade openness, democracy, and executive and political competition constraints. Government spending is influenced by foreign aid, tax revenue, current account balance, and trade openness positively, and the results are significant. The positive impact on the current account balance is that import and export goods and services enhance government spending. In contrast, debt insignificantly influences government spending, but interacts with interest rates; this same variable negatively influences government spending. Every debt has different rules of thumb to pay back the primary amount of money. An intuitive sense is that a high-interest rate leads to a burden to donor countries' counterparts. In this research, some political variables such as democracy, constraints on the executive, and political competition are addressed. These variables are essential for analyzing the economic decisions that have been taken place in South Asian countries. Increasing a level of democracy will be a $0.06 \%$ increase in countries' government spending. The result is statistically significant at the $10 \%$ level. Government spending rises positively, increasing a level of constraint on the executive. Similar way, political completion directly influences government spending. Hence, the findings from descriptive and empirical analysis comply with the flow of theory and the field. 
Business Review- A Journal of Business Administration Discipline, Khulna University, Volume: 14, Number: 1, January-June 2019, pp.17-28 (Print ISSN: 1811-3788; Online ISSN: 2664-3502)

\section{Conclusion}

The study intended to examine the effects of foreign aid, debt, and tax revenue on government spending in South Asia. These macroeconomic variables raise an unmitigated debate regarding aid effectiveness, debt burden, and causes behind the low amount of tax revenue, role of public policy, government's expenditure pattern, and many more. This debate concludes with different answers in the different economic situations around the world. This research explicitly wants to observe the effects of these variables on government spending in South Asia, where aid and debt dependency, thin tax base, and budget deficit are intensely attached to the economy. The study presented the background with literature support about the issue. Then the panel data set has been analyzed with a panel regression model. The within-group fixed effect estimation result shows a positive relationship between the variables. If foreign aid, debt, and tax revenue increase, government spending will rise. More spending through aid and debt not always gives us the expected development as it creates more dependency on external support. Here, debt with interest rates makes spending more for the countries. The government should try to avoid the trap of debt as the economy becomes vulnerable in its presence when the investment made in the industrial sector the government spending influenced by it positively. Current account balance, as well as trade openness, also shows positivity towards government spending. The study finds that democracy, a constraint on the executive, and political competition positively impact government spending. Increasing the index value supports the positive trend of government spending.

Thus, the main policy implications are that foreign aid should be appropriate and in that particular purpose for which it has been specified. The collaboration of the ministry of finance, ministry of planning, and ministry of foreign affairs can modify the foreign aid and debt more promising than before. Foreign aid should not be consumed for any recurrent expenditure (interest payment, institutional cost, subsidies). All in all, priority should be on enhancing the development expenditure; thus, the productivity grows. Increasing tax revenue is another way to sustainably upholding government spending. At first, it should be ensured that the taxes have been appropriately collected without any institutional corruption. The taxpayers are not taking any opportunities from the system's gap to avoid tax paying. Therefore, the National Board of Revenue (N.B.R.) might address the tax department efficiently. Then policies should be taken for increasing tax revenue and decreasing debt burden for efficient government spending. Export promotion and import substitution industries, large-scale investment, and efficient fiscal policies will increase productivity and directly influence spending. It is time to attain sustainable development goals, efficient use of ODA can help achieve 17 goals, especially no poverty, and zero hunger. Japan covers ODA into economic growth, and it reflects on sustainable development goals. On the other hand, the debt burden shrinks the possibility of opting out of poverty. The most important thing is that policies should not only be in the papers or the scholars' minds, but it should also make changes in people and institutional behaviour. Especially in getting aid or taking a loan, the management of finance should handle it with honesty. There should be strong laws and punishment against any corruption. That is, good governance and a proper macroeconomic management system area must need. An efficient and effective governance system will create more accountability towards the people. It will increase the number of development works. In that way, the effect could be positive and sustainable for the South Asian economy. Last, on the list, the shortcomings of this research are presented here. Data are considered up to 2014, but it can be updated. Secondly, a dynamic empirical method can be introduced to get a more decisive outcome. Thirdly, the list of variables can be improved to make it more rigorous. There is a scope of future research options in this same topic by analyzing the limitations.

\section{References}

Abizadeh, S. and Yousefi, M. (1996),"Industrialization and government expenditures: The case of South Korea,"International Economic Journal, Vol. 10, No. 1, pp. 83-94.

Akram, N. (2016),"Public debt and pro-poor economic growth evidence from South Asian countries,"Ekonomskaistraživanja, Vol. 29, No. 1, pp. 746-757.

Anderson, W., Wallace, M.S., and Warner, J.T. (1986),"Government spending and taxation: What causes what?", Southern Economic Journal, pp. 630-639.

Benarroch, M. and Pandey, M. (2012),"The Relationship between Trade Openness and Government size: Does disaggregating government expenditure matter?", Journal of Macroeconomics, Vol. 34, No. 1, pp. 239-252. 
Business Review- A Journal of Business Administration Discipline, Khulna University, Volume: 14, Number: 1, January-June 2019, pp.17-28 (Print ISSN: 1811-3788; Online ISSN: 2664-3502)

Bhattarai, B.P. (2007),"Foreign aid and government's fiscal behaviour in Nepal: An empirical analysis," Economic Analysis and Policy, Vol. 37, No. 1, pp. 41-60.

Bohn, H. (1998),"The behaviour of U.S. public debt and deficits,"The Quarterly Journal of Economics, Vol. 113, No. 3, pp. 949-963.

Bräutigam, D.A. and Knack, S. (2004),"Foreign Aid, Institutions, and Governance in Sub-Saharan Africa,"Economic Development and Cultural Change, Vol. 52, No. 2, pp. 255-285.

Burnside, C. and Dollar, D. (2000),"Aid, Policies, and Growth,"American Economic Review, Vol. 90, No. 4, pp. $847-868$.

Carruthers, J.I. and Ulfarsson, G.F. (2003),"Urban sprawl and the cost of public services,"Environment and Planning B: Planning and Design, Vol. 30, No. 4, pp. 503-522.

Chang, T. and Chiang, G. (2009),"Revisiting the government revenue-expenditure nexus: Evidence from 15 OECD countries based on the panel data approach",Czech Journal of Economics and Finance (Finance a uver), Vol. 59, No.2, pp. 165-172.

Chatterjee, S., Giuliano, P. and Kaya, I. (2012),"Where has all the money gone? Foreign aid and the composition of government spending", The B.E. Journal of Macroeconomics, Vol.12, No. 2, pp. 25-35.

Chaudhary, M.A., Anwar, S. and Tahir, P. (2000),"Foreign debt, dependency, and economic growth in South Asia,"The Pakistan Development Review, Vol.11 No. 1, pp. 551-570.

Combes, J.L., Ouedraogo, R. and Tapsoba, S. (2016),"What does aid do to fiscal policy? New evidence", Journal of Economics and Finance, Vol. 39, No. 3, pp. 105-156.

Devarajan, S., Swaroop, V. and Zou, H.F. (1996),"The composition of public expenditure and economic growth,"Journal of Monetary Economics, Vol. 37, No. 2, pp. 313-344.

Durbarry, R., Gemmell, N. and Greenaway, D. (1998), "New evidence on the impact of foreign aid on economic growth,"Centre for Research in Economic Development and International Trade, Vol. 98, No. 4, pp. 15-30.

Dwyer Jr, G.P. (1982),"Inflation and government deficits,"Economic Inquiry, Vol. 20, No. 3, pp. 315-329.

Eita, J.H. and Mbazima, D. (2008),"The causal relationship between government revenue and expenditure in Namibia,"Journal of Economic and Financial Sciences, Vol. 2, No. 2, pp. 175-186.

Feinman, J.N. (1993),"Reserve requirements: History, current practice, and potential reform," Fed. Res. Bull., Vol. 79 , p. 569.

Feyzioglu, T., Swaroop, V. and Zhu, M. (1998), "A panel data analysis of the fungibility of foreign aid," The World Bank Economic Review, Vol. 12, No. 1, pp. 29-58.

Foster, M. and Fozzard, A. (2000),"Aid and public expenditure: A guide," Working Paper, No. 141, Overseas Development Institute (ODI), London.

Gupta, S. and Tareq, S. (2008),"Mobilizing revenue," Finance and Development, Vol. 45, No. 3, pp. 44-77.

Herzer, D. and Morrissey, O. (2013),"Foreign aid and domestic output in the long run,"Review of World Economics, Vol. 149, No. 4, pp. 723-748.

I.M.F. (2017) World Economic Outlook Database 2017, International Monetary Fund (I.M.F.), Washington, D.C.

Laubach, T. (2009),"New evidence on the interest rate effects of budget deficits and debt,"Journal of the European Economic Association, Vol. 7, No. 4, pp. 858-885.

Maitra, B. (2019), "Macroeconomic impact of public debt and foreign aid in Sri Lanka,"Journal of Policy Modeling, Vol. 41, No. 2, pp. 372-394.

Martinez-Vazquez, J., Moreno-Dodson, B. and Vulovic, V. (2012), "The impact of tax and expenditure policies on income distribution: Evidence from a large panel of countries", Journal of Financial Express, Vol. 8, No. 6, pp. 152-168.

Martins, P.M. (2009), "The impact of foreign aid on government spending, revenue and domestic borrowing in Ethiopia,"Economic Alternatives for Growth, Employment and Poverty Reduction, Vol.15, No. 1, pp. 100136.

McGillivray, M. and Ouattara, B. (2005), “Aid, debt burden and government fiscal behaviour in Côte d'Ivoire”, Journal of African Economies, Vol. 14, No. 2, pp. 247-269. 
Mehrara, M., Pahlavani, M. and Elyasi, Y. (2011),"Government revenue and government expenditure nexus in Asian countries: Panel cointegration and causality,"International Journal of Business and Social Science, Vol. 2, No. 7, pp. 199-207.

Morrissey, O. (2012),"Aid and government fiscal behaviour: What does the evidence say?"Working Paper, No. 2012/01, World Institute for Development Economics Research (WIDER), Helsinki.

Morrissey, O. (2015),"Aid and government fiscal behaviour: Assessing recent evidence," World Development, Vol. 69, pp. 98-105.

Njeru, J. (2003),"The impact of foreign aid on public expenditure: The case of Kenya,"African Economic Research Consortium, p. 135.

Oboh, C.S. and Isa, E.F. (2012),"An empirical investment of multiple tax practices and taxpayer's compliance in Nigeria", No.48, pp. 42-52.

Ouattara, B. (2006),"Aid, debt and fiscal policies in Senegal,"Journal of International Development, Vol. 18, pp. $1105-1122$.

Padda, I.U.H. and Akram, N. (2009),"The impact of tax policies on economic growth: Evidence from South-Asian economies,"The Pakistan Development Review, pp. 961-971.

Pankaj, A.K. (2005),"Revisiting foreign aid theories,"International Studies, Vol. 42, No. 2, pp. 103-121.

Remmer, K.L. (2004),"Does foreign aid promote the expansion of government?", American Journal of Political Science, Vol. 48, No. 1, pp. 77-92.

State Bank of Pakistan (2017), Domestic Markets \& Monetary Management Department, Pakistan, Karachi.

Siddiqui, R. and Malik, A. (2001),"Debt and economic growth in South Asia," The Pakistan Development Review, Vol.12, No. 2, pp. 677-688.

Stigler, G.J. (1972),"Economic competition and political competition," Public Choice, Vol. 13, No. 1, pp. 91-106.

Tanner, E. (1994),"The effect of government spending on the current account, output, and expenditures: Evidence from Latin America,"Journal of Development Economics, Vol. 44, No. 2, pp. 287-310.

W.B. (2017),"World Development Indicators 2017",available at https://databank.worldbank.org/source/worlddevelopment-indicators (accessed on 06/11/2019) 